\title{
Floatation of Activated Sludge by Nascent Prepared Carbon Dioxide
}

\author{
تعويم الحمأة المنشطة بإستخدام ثانى اكسيد الكربون المولا حديثا
}

\author{
Hoda F. El-Gamal ${ }^{(1)}$, Kamal E. Radwan ${ }^{(1)}$, Kareem M. Fouad ${ }^{(2)}$
}

Public Works - Eng. Depart. - Faculty of Eng. - Mansoura University ${ }^{(1)}$

Civil Eng. Depart. - Higher Institute of Eng. \& Technology - New Damietta ${ }^{(2)}$

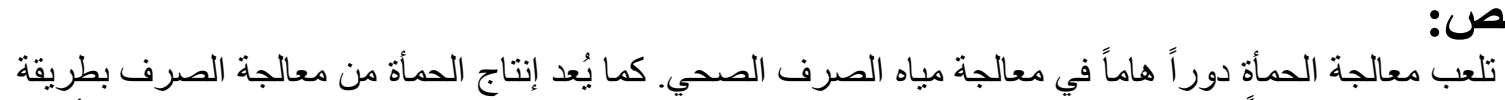

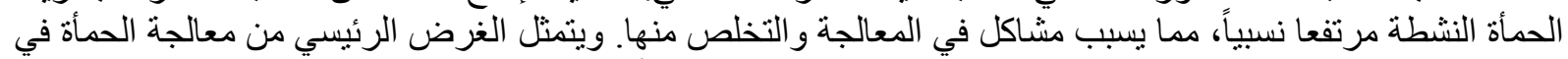

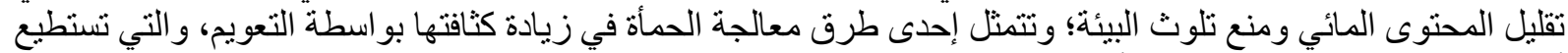

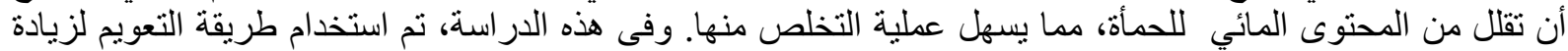

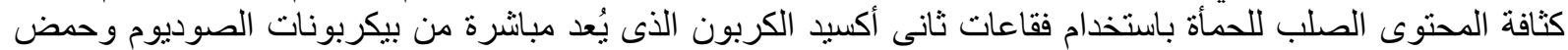

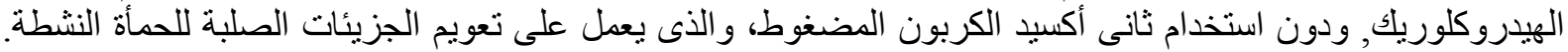

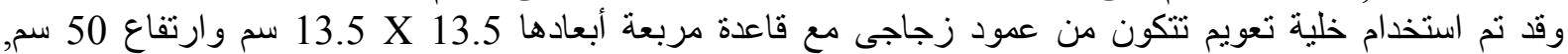

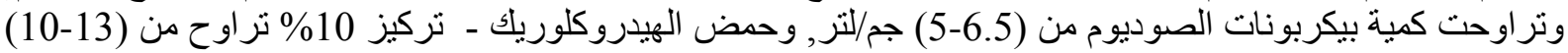

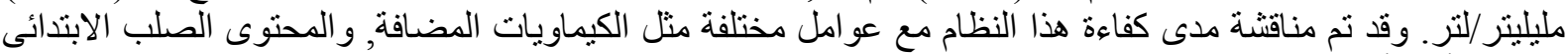

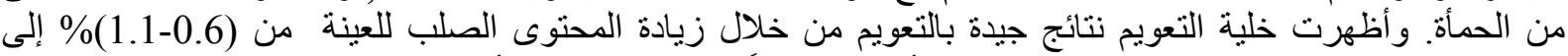

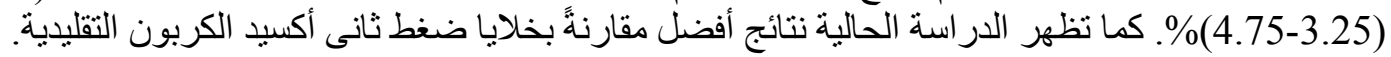

\begin{abstract}
Sludge treatment plays an important role in the treatment of wastewater. The production of sludge from wastewater treatment by the activated sludge method is relatively high, which causes problems in the treatment and disposal processes. The main purpose of sludge treatment is to reduce its water content, in addition to the prevention of pollution of the environment; one method of the activated sludge treatment methods is "Thickening by Floatation", which could reduce the water content of the sludge, facilitating the disposal process. In the present study, the floatation method is used to increase the sludge solid content by bubbles of carbon dioxide, which is directly prepared from sodium bicarbonate and hydrochloric acid, without the use of pressurized $\mathrm{CO}_{2}$, which results in the floatation of activated sludge solid particles. A floatation cell, composed of a glass column with a square base $(13.5 \times 13.5 \mathrm{~cm})$ and height $(50 \mathrm{~cm})$, is used. The quantity of sodium bicarbonate ranged from 5 to $6.5 \mathrm{~g} / \mathrm{L}$; and that of the hydrochloric acid (10\% concentration) ranged from 10 to $13 \mathrm{~mL} / \mathrm{L}$. The efficiency of this system was discussed with varying parameters, such as chemicals addition and initial solid content of sludge. The floatation cell showed a good result, regarding the increasing of the thickened sludge by floatation, from (0.6-1.1) \% of solid content to (3.25-4.75) \%; in addition, the current study has also shown better results, compared to the conventional pressurized $\mathrm{CO}_{2}$ cell.
\end{abstract}

\section{Key words}

Flotation, Activated Sludge, Carbon Dioxide

\section{Nomenclature}

\begin{tabular}{|l|l|}
\hline $\mathrm{H}_{\mathrm{i}}$ & Initial Liquor Height \\
\hline $\mathrm{W}_{\mathrm{i}}$ & Initial Water Content \\
\hline $\mathrm{TDS}$ & Total Dissolved Solids \\
\hline $\mathrm{S}_{\mathrm{i}}$ & Initial Solid Content \\
\hline $\mathrm{H}_{\mathrm{f}}$ & Final Liquor Height \\
\hline $\mathrm{W}_{\mathrm{f}}$ & Final Water Content \\
\hline $\mathrm{SVI}$ & Sludge Volume Index \\
\hline $\mathrm{S}_{\mathrm{f}}:$ & Final Solid Content \\
\hline
\end{tabular}




\section{Introduction}

As a general idea, the main purpose of sludge treatment is to reduce its water content, enhancing its properties and making it easy to handle [1].

Dewatering of Waste-Activated Sludge (WAS) is a physical unit operation, used to reduce its moisture content for purposes such as reuse and disposal. Although there are various traditional methods used for this process, the current methods still need to be improved or simplified [7].

Flotation is an alternative; as it has high efficiency [3]. It produces better water quality; and it could be operated at high surface loadings, resulting in relatively small and shallow plants; and it could be started up quickly, with a steady water quality being achieved within $45 \mathrm{~min}$. Also, the solid concentration of the sludge produced is significantly higher (about 3 percent) than that of the sludge produced by sedimentation. [11]

The use of flotation has great potential, due to the high throughput and the efficiency of modern equipment [4]. In the dissolved air flotation technique, the bubbles are formed by nucleation on the particles. In this technique, a substantial portion of the clarified effluent must be recycled, compressed from 4 up to 5 atm and saturated with air. As for the flotation stage in the traditional methods, the air is dissolved in the wastewater under a pressure of several atmospheres, followed by a release to the atmospheric level, using the 'supersaturate and release' method [10]. In dispersed air flotation, the air bubbles are generated either by electrolysis or by forcing the air through porous glass, single orifice or other suitable Spurger. In this type of flotation, the gas flow rate may be an important operating variable. The dispersed air has the advantage of eliminating the need for recycling [5].

Flotation of waste-activated sludge by micro bubbles of carbon dioxide $\left(\mathrm{CO}_{2}\right)$ gas. It is widely known that $\mathrm{CO}_{2}$ gas has a serious impact on the global warming of Earth; and so many efforts have been devoted to collect the $\mathrm{CO}_{2}$ gas from the burning gas of fossil fuels. [2].

Floatation of the sludge using mixture of $(80 \%$ $\mathrm{N}_{2}+20 \% \mathrm{CO}_{2}$ )-gases, model-gas, improves the dewatering results and is a new technique [6], [7].

Separation of particles by flotation falls under the same laws as sedimentation, but in a "reverse field of force". The governing equation in air flotation separation, as well as in all gravity controlled processes, is the Stoke's Law (at least in laminar flow); which is used to compute the rise rate of bubble flocs, agglomerates, and bubble-oil aggregation [8], [9].

$\mathrm{Vt}=\frac{\mathrm{gD}^{2}\left(\rho_{\mathrm{a}}-\rho_{\mathrm{o}}\right)}{18 \mu}$

Where $\mathbf{V}_{\mathbf{t}}$ is the terminal rise velocity, $\mathbf{g}$ is the gravitational constant, $\mathbf{D}$ is the effective diameter of the agglomerate, $\rho_{\mathbf{a}}$ is the density of the agglomerate, $\boldsymbol{\rho}_{\mathrm{o}}$ is the density of the aqueous phase, $\boldsymbol{\mu}$ is the viscosity of the aqueous phase.

\section{Experimental Set-Up And Procedure}

A practical sequential program has been implemented. This program consists of four phases as shown in (Table 1). The experimental work was located at the wastewater treatment plant of Mansoura City in Egypt. The materials and the equipment used in this study were utilized in both of bench scale studies, and for studying the system of waste-activated sludge (WAS) treatment technique.

The main objective of the proposed system is to deliver the waste-activated sludge that has been mixed with hydrochloric acid, and then mix it with sodium bicarbonate. The flotation cell composed of a glass column with a square base (13.5 x 13.5 $\mathrm{cm})$ and height $(50 \mathrm{~cm})$. As for the separated liquor exit, there is a valve set on the center of the squared base. The separated thickened sludge's exit was set on a height $(20 \mathrm{~cm})$ from the base in one of the four sides of the column, as shown in (Fig. 1). 


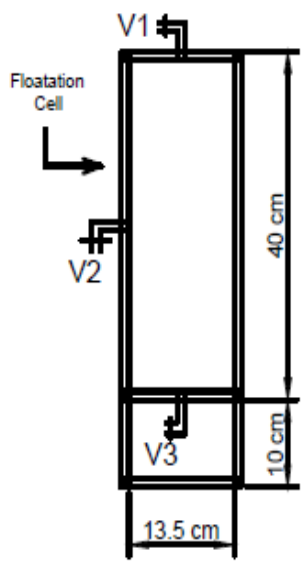

V1- Sludge inlet

V2- Thickened sludge outlet

V3- Liquor outlet

\section{Fig.1 The Experimental Set-up}

The WAS is mixed with hydrochloric acid at a $10 \%$ concentration in the external tank. $\mathrm{NaHCO}_{3}$ is added to the experimental set up, before introducing the mixed sludge. Then, we pour the mixed WAS into the experimental set up. The main objective of adding chemicals is to produce carbon dioxide, which is produced according to the following equation:

$$
\begin{aligned}
& \mathrm{HCL}+\mathrm{NaHCO}_{3} \longrightarrow \mathrm{H}_{2} \mathrm{O}+\mathrm{NaCL}+ \\
& \mathrm{CO}_{2}
\end{aligned}
$$

The final height of separated liquor $\mathrm{H}_{\mathrm{f}}$ is shown in (Table 2). The numbers shown in the table refer to the samples' numbers.

\section{Laboratory Experiments}

Water Content (WC \%): This test is performed to determine the water (moisture) content of soils. The water content is the ratio, expressed as a percentage, of the mass of "pore" or "free" water in a given mass of soil to the mass of the dry soil solids. For many soils, the water content may be an extremely important index, used for establishing the relationship between the way a soil behaves and its properties. The consistency of a fine-grained soil largely depends on its water content. The water content is also used in expressing the phase relationships of air, water, and solids in a given volume of soil.

$W . C=\frac{\text { Wet sludge }(\mathrm{wt})-\text { Dry sludge }(\mathrm{wt})}{\text { Wet sludge }(\mathrm{wt})} \%$
$\mathrm{pH}$ : In chemistry, $\mathrm{pH}$ is a measure of the acidity or basicity of an aqueous solution. Solutions with a $\mathrm{pH}$ less than 7 are said to be acidic, and solutions with a $\mathrm{pH}$ greater than 7 are basic or alkaline. Pure water has a $\mathrm{pH}$ very close to 7 . The device used (VWR sympHony SB70P digital bench top $\mathrm{pH}$ meter with electrode w/warranty).

TDS: A TDS Meter indicates the Total Dissolved Solids (TDS) of a solution, i.e. the concentration of dissolved solids in it. TDS meter measures the conductivity of the solution and estimates the TDS from that. Dissolved organic solids such as sugar and microscopic solid particles such as colloids, do not significantly affect the conductivity of a solution; therefore, a TDS meter does not include them in its reading. The device used (Milwaukee Instruments Mi170 Auto ranging Cond/TDS/NaCl/Temp Lab Bench Meter). Conductivity: An electrical conductivity meter (EC meter) measures the electrical conductivity in a solution. It is commonly used in hydroponics, aquaculture and fresh-water systems to monitor the amount of nutrients, salts or impurities in the water. The device used (Milwaukee Instruments Mi170 Auto ranging Cond/TDS/NaCl/Temp Lab Bench Meter).

Sludge volume index (SVI): The sludge volume index (SVI) is the volume in milliliters occupied by $1 \mathrm{~g}$ of a suspension after a 30-min. settling. SVI typically is used to monitor settling characteristics of activated sludge and other biological suspensions. It determines the suspended solids concentration of a well-mixed sample of the suspension. It determines the 30-min. settled sludge volume.

SVI $=\frac{\text { Settled sludge volume }\left(\frac{\mathrm{ml}}{\mathrm{l}}\right) \times 1000}{\text { Suspended solids }\left(\frac{\mathrm{mg}}{\mathrm{l}}\right)}$

\section{Operational Condition and the Experimental Parameters}

The experimental methodology is divided into four phases. In all phases, the final liquor height $\mathrm{H}_{\mathrm{f}}$, the final solid 
content $\mathrm{S}_{\mathrm{f}}, \mathrm{pH}$, TDS and the conductivity are all obtained. During all other phases, $\mathrm{pH}, \mathrm{SVI}$ and $\mathrm{WC} \%$ are un-controlled parameters. The control parameters are the initial height of WAS, the amount of sodium bicarbonate and the hydrochloric acid. The experimental operation is shown in (Fig. 2).

Table 1 The Operational Conditions

\begin{tabular}{|c|c|c|c|c|c|c|c|c|}
\hline \multicolumn{3}{|c|}{ samples } & 1 & 2 & 3 & 4 & 5 & 6 \\
\hline & $\begin{array}{c}\mathrm{NaHCO}_{3} \\
\mathrm{gm} / \mathrm{L}\end{array}$ & $\begin{array}{c}\mathrm{HCl} \\
\mathrm{mL} / \mathrm{L}\end{array}$ & $\mathrm{S}_{\mathrm{i}} \%$ & $\mathbf{S}_{\mathbf{i}} \%$ & $\mathbf{S}_{\mathbf{i}} \%$ & $\mathbf{S i}_{\mathbf{i}} \%$ & $\mathrm{~S}_{\mathrm{i}} \%$ & $\mathbf{S}_{\mathbf{i}} \%$ \\
\hline Phase 1 & 5 & 10 & \multirow{4}{*}{0.58} & \multirow{4}{*}{0.71} & \multirow{4}{*}{0.89} & \multirow{4}{*}{0.933} & \multirow{4}{*}{0.98} & \multirow{4}{*}{1.1} \\
\hline Phase 2 & 5.5 & 11 & & & & & & \\
\hline Phase 3 & 6 & 12 & & & & & & \\
\hline Phase 4 & 6.5 & 13 & & & & & & \\
\hline \multicolumn{9}{|c|}{ Where $\mathbf{S}_{\mathbf{i}} \%$ is the initial solid content } \\
\hline
\end{tabular}

Table 2 The Initial Sludge Characteristics and Parameters

\begin{tabular}{|c|c|c|c|c|c|c|c|}
\hline \multirow{2}{*}{$\begin{array}{c}\text { Sample } \\
\text { No. }\end{array}$} & \multicolumn{9}{|c|}{ Conditions } \\
\hline & $\mathbf{H}_{\mathbf{i}}$ & $\mathbf{W}_{\mathbf{i}}$ & $\mathbf{S}_{\mathbf{i}}$ & $\mathbf{p H}$ & $\mathbf{T D S}$ & $\mathbf{S V I}$ & Conductivity \\
\hline $\mathbf{1}$ & $\mathbf{C m}$ & - & $\mathbf{\%}$ & - & $\mathbf{m g} / \mathbf{L}$ & - & $\boldsymbol{\mu S} / \mathbf{c m}$ \\
\hline $\mathbf{2}$ & 24.5 & 0.9942 & 0.58 & 6.76 & 233 & 22.6 & 388 \\
\hline $\mathbf{3}$ & 24.5 & 0.9929 & 0.71 & 6.91 & 260 & 19.59 & 413 \\
\hline $\mathbf{4}$ & 24.5 & 0.9907 & 0.89 & 6.66 & 320 & 19.46 & 535 \\
\hline $\mathbf{5}$ & 24.5 & 0.9902 & 0.98 & 6.86 & 238 & 13.35 & 396 \\
\hline $\mathbf{6}$ & 24.5 & 0.989 & 1.1 & 6.77 & 329 & 16.85 & 546 \\
\hline
\end{tabular}

\section{Results and Discussion}

We have studied the effect of carbon dioxide bubbles on sludge thickening by using the amounts of $(5,5.5,6,6.5) \mathrm{gm} / \mathrm{L}$ $\mathrm{NaHCO}_{3}$ and $(10,11,12,13) \mathrm{mL} / \mathrm{L} \mathrm{HCL}$, at a $10 \%$ concentration volume. In addition, the concern is about the reduction in retention time. The results obtained from the carried out experiments could be classified in two parts separately as illustrated in the following paragraphs:

\section{Final Height of WAS $\left(\mathbf{H}_{\mathbf{f}}\right)$ :}

Figures (3, 5, 7, 9) show the relation between the Final liquor height and the retention time. It reveals that the liquor height increases with time up till 30 minutes.

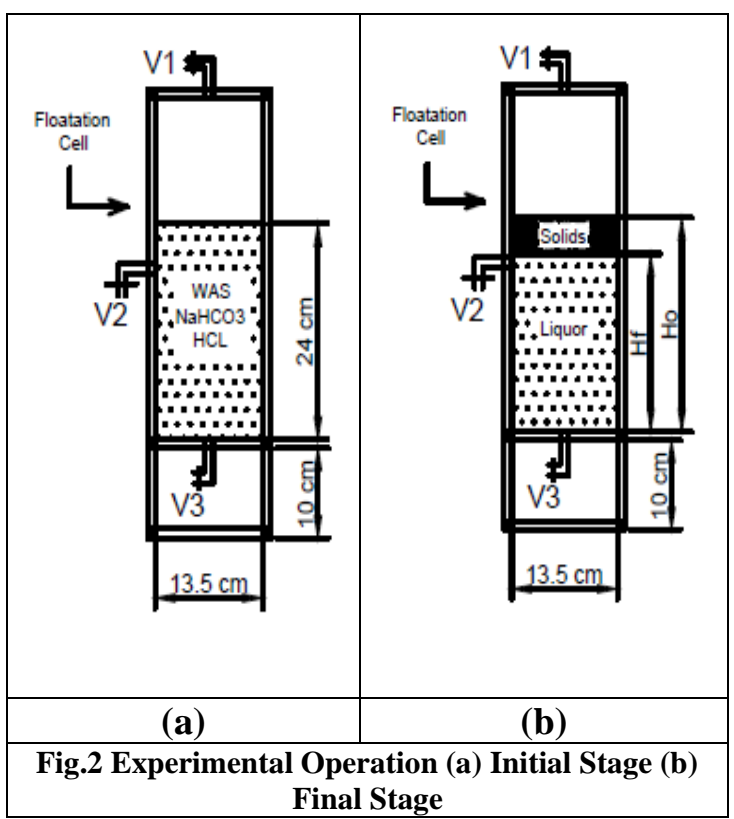


Final Solid Content $\left(\mathbf{S}_{\mathbf{f}} \%\right)$ :

Figures $(4,6,8,10)$ show the relation between the final solid content and the retention time. After 15 minutes, we reached approximately (95.5 - 97.5) \% from the final solid content after 30 minutes; this shows the high decrease in retention time for the WAS thickening process.

Table 3 The First Phase Results

\begin{tabular}{|c|c|c|c|c|c|c|}
\hline \multirow{2}{*}{$\begin{array}{c}\text { Sample } \\
\text { No. }\end{array}$} & \multicolumn{7}{|c|}{ Results } \\
\cline { 2 - 7 } & $\mathbf{H}_{\mathbf{f}}$ & $\mathbf{W}_{\mathbf{f}}$ & $\mathbf{S}_{\mathbf{f}}$ & $\mathbf{p H}$ & $\mathbf{T D S}$ & Conductivity \\
\hline & $\mathbf{C m}$ & - & $\mathbf{\%}$ & - & $\mathbf{m g} / \mathbf{L}$ & $\boldsymbol{\mu S} / \mathbf{c m}$ \\
\hline $\mathbf{1}$ & 19.7 & 0.9715 & 2.85 & 5.71 & 1720 & 2830 \\
\hline $\mathbf{2}$ & 21.25 & 0.9655 & 3.45 & 5.92 & 1890 & 3100 \\
\hline $\mathbf{3}$ & 20.65 & 0.9656 & 3.44 & 6.3 & 1986 & 3187 \\
\hline $\mathbf{4}$ & 19.5 & 0.9727 & 2.73 & 5.7 & 1780 & 2843 \\
\hline $\mathbf{5}$ & 21 & 0.9652 & 3.48 & 5.98 & 1840 & 3130 \\
\hline $\mathbf{6}$ & 21.15 & 0.9645 & 3.55 & 6.35 & 1726 & 2730 \\
\hline
\end{tabular}

Table 4 The Second Phase Results

\begin{tabular}{|c|c|c|c|c|c|c|}
\hline \multirow{2}{*}{$\begin{array}{c}\text { Sample } \\
\text { No. }\end{array}$} & \multicolumn{7}{|c|}{ Results } \\
\hline & $\mathbf{H}_{\mathbf{f}}$ & $\mathbf{W}_{\mathbf{f}}$ & $\mathbf{S}_{\mathbf{f}}$ & $\mathbf{p H}$ & $\mathbf{T D S}$ & Conductivity \\
\hline $\mathbf{1}$ & 21.22 & - & $\mathbf{\%}$ & - & $\mathbf{m g} / \mathbf{L}$ & $\boldsymbol{\mu S} / \mathbf{c m}$ \\
\hline $\mathbf{2}$ & 21 & 0.966 & 4.34 & 5.71 & 2090 & 3400 \\
\hline $\mathbf{3}$ & 20.1 & 0.9619 & 3.81 & 5.92 & 2430 & 3820 \\
\hline $\mathbf{4}$ & 18.6 & 0.9637 & 3.63 & 5.3 & 2600 & 4260 \\
\hline $\mathbf{5}$ & 20 & 0.9647 & 3.53 & 5.98 & 1740 & 2970 \\
\hline $\mathbf{6}$ & 19.2 & 0.9627 & 3.73 & 6.35 & 2100 & 3539 \\
\hline
\end{tabular}

Table 5 The Third Phase Results

\begin{tabular}{|c|c|c|c|c|c|c|}
\hline \multirow{2}{*}{$\begin{array}{c}\text { Sample } \\
\text { No. }\end{array}$} & \multicolumn{7}{|c|}{ Results } \\
\cline { 2 - 7 } & $\mathbf{H}$ & $\mathbf{W}_{\mathbf{f}}$ & $\mathbf{S}_{\mathbf{f}}$ & $\mathbf{p H}$ & $\mathbf{T D S}$ & Conductivity \\
\hline & $\mathbf{C m}$ & - & $\mathbf{\%}$ & - & $\mathbf{m g} / \mathbf{L}$ & $\boldsymbol{\mu S} / \mathbf{c m}$ \\
\hline $\mathbf{1}$ & 21.8 & 0.9467 & 5.33 & 6.13 & 2140 & 3510 \\
\hline $\mathbf{2}$ & 21 & 0.9537 & 4.63 & 6.21 & 2050 & 3390 \\
\hline $\mathbf{3}$ & 21.5 & 0.9568 & 4.32 & 6.18 & 2600 & 4330 \\
\hline $\mathbf{4}$ & 20.2 & 0.9562 & 4.38 & 6.13 & 2360 & 3876 \\
\hline $\mathbf{5}$ & 21.25 & 0.9544 & 4.56 & 6.39 & 1920 & 3190 \\
\hline $\mathbf{6}$ & 22 & 0.9505 & 4.95 & 6.05 & 2500 & 4230 \\
\hline
\end{tabular}

Table 6 The Fourth Phase Results

\begin{tabular}{|c|c|c|c|c|c|c|}
\hline \multirow{2}{*}{$\begin{array}{c}\text { Sample } \\
\text { No. }\end{array}$} & \multicolumn{7}{|c|}{ Results } \\
\hline & $\mathbf{H}_{\mathbf{f}}$ & $\mathbf{W}_{\mathbf{f}}$ & $\mathbf{S}_{\mathbf{f}}$ & $\mathbf{p H}$ & $\mathbf{T D S}$ & Conductivity \\
\hline $\mathbf{1}$ & $\mathbf{C m}$ & - & $\mathbf{\%}$ & - & $\mathbf{m g} / \mathbf{L}$ & $\boldsymbol{\mu} \mathbf{S} / \mathbf{c m}$ \\
\hline $\mathbf{2}$ & 21.5 & 0.9486 & 5.14 & 6.11 & 2280 & 3760 \\
\hline $\mathbf{3}$ & 20.55 & 0.9505 & 4.95 & 6.28 & 2330 & 3700 \\
\hline $\mathbf{4}$ & 20.25 & 0.9506 & 4.94 & 6.23 & 2830 & 4700 \\
\hline $\mathbf{5}$ & 20.25 & 0.9539 & 4.6 & 6.08 & 2470 & 4020 \\
\hline $\mathbf{6}$ & 20.15 & 0.9554 & 4.46 & 6.29 & 1940 & 3230 \\
\hline
\end{tabular}




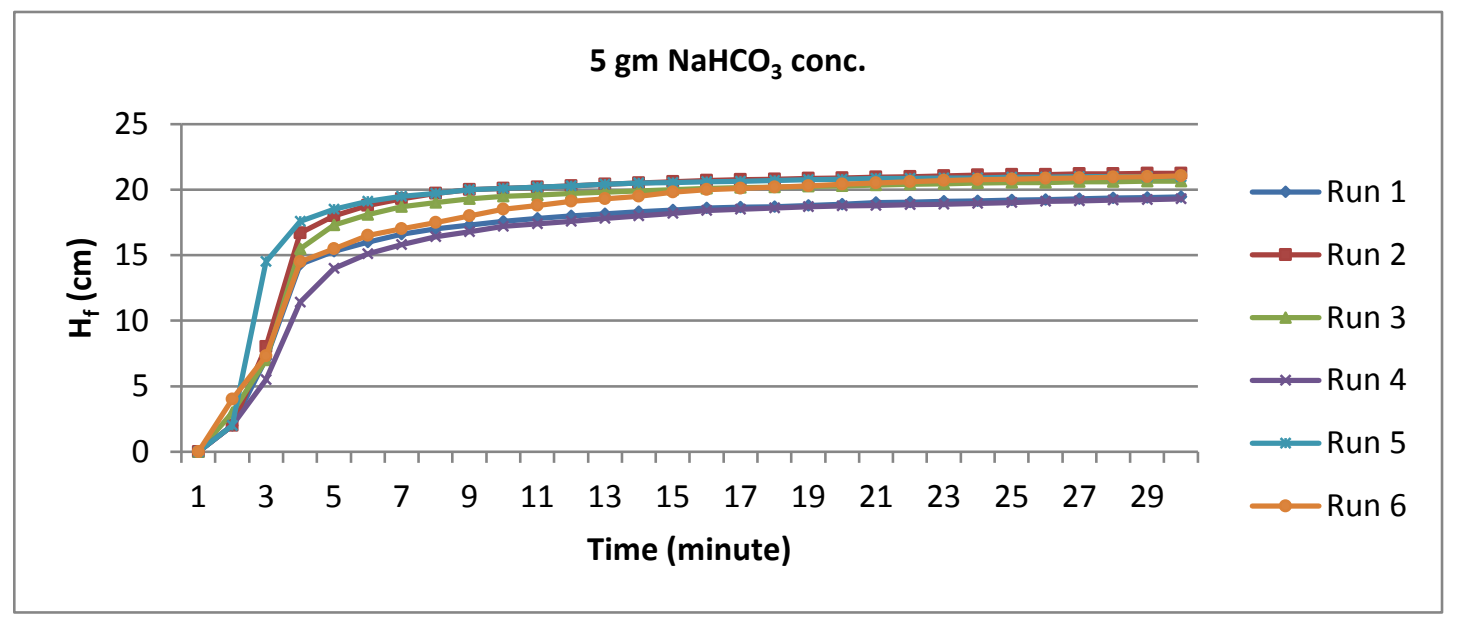

Fig.3 First Phase: The Relation between Final Liquor Height and Time

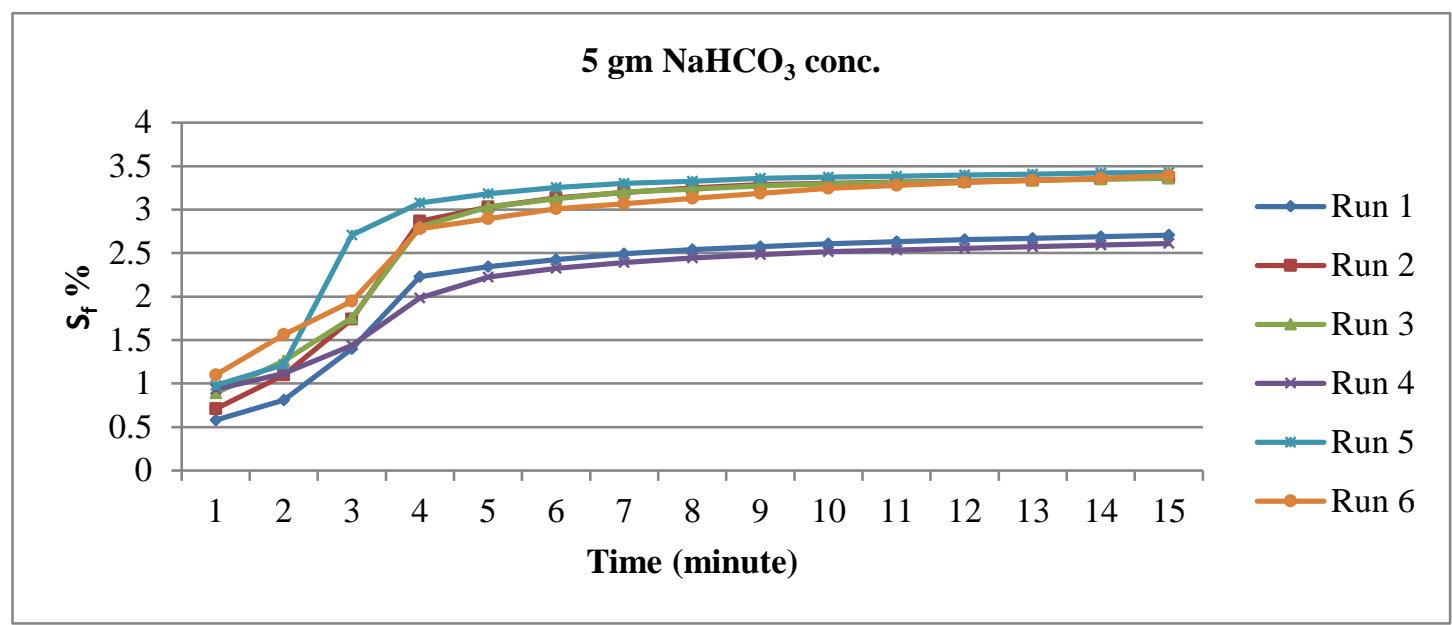

Fig.4 First Phase: The Relation between Final Solid Content and Time

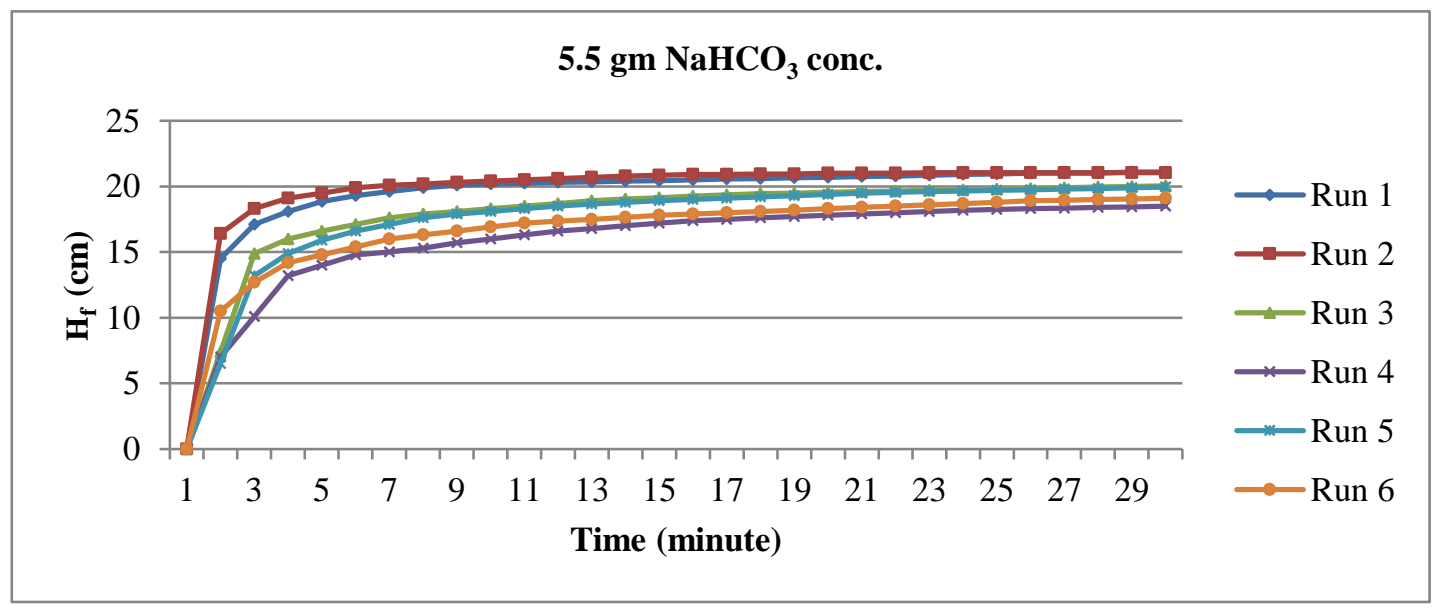

Fig.5 Second Phase: The Relation between Final Liquor Height and Time 


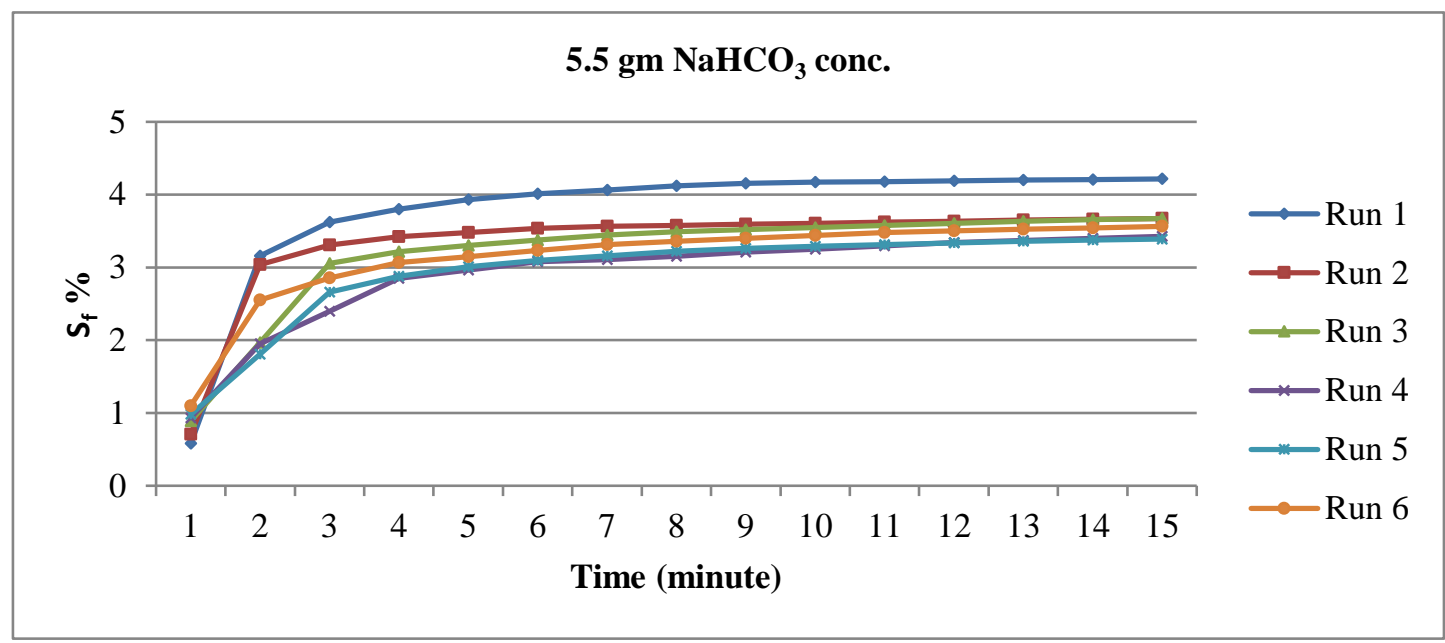

Fig.6 Second Phase: The Relation between Final Solid Content and Retention Time

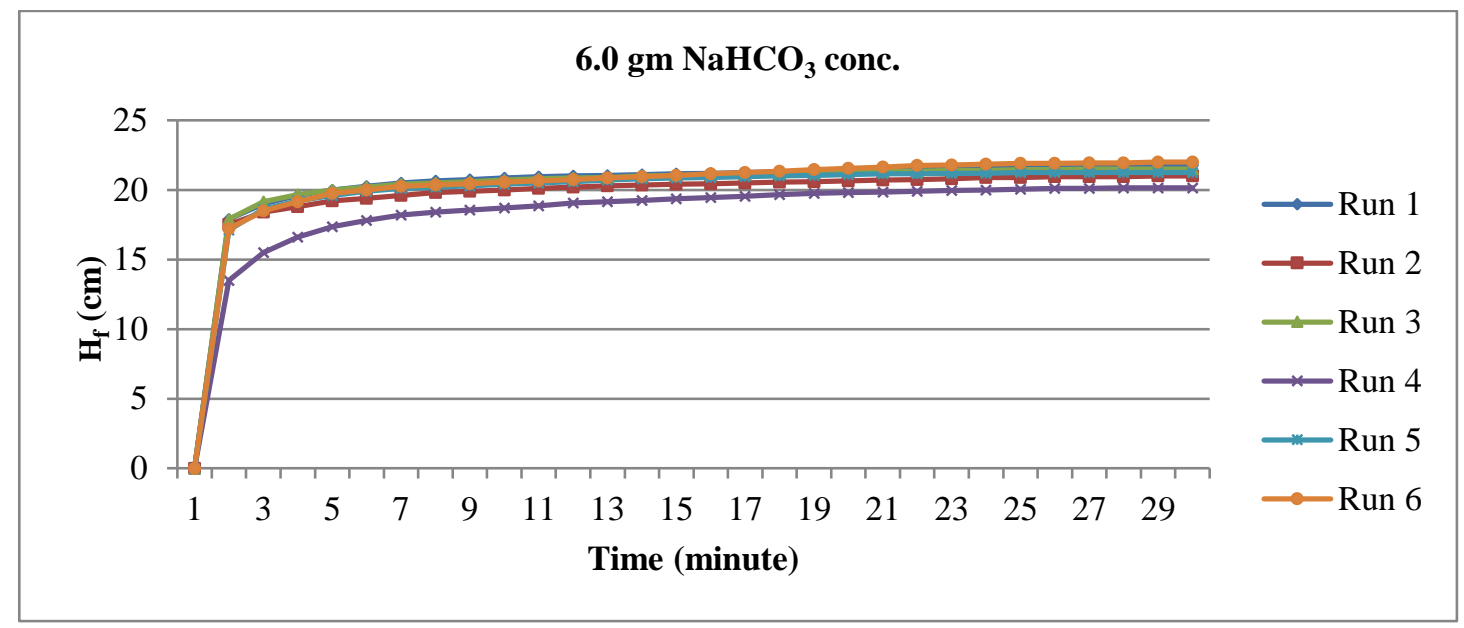

Fig.7 Third Phase: The Relation between Final Liquor Height and Time

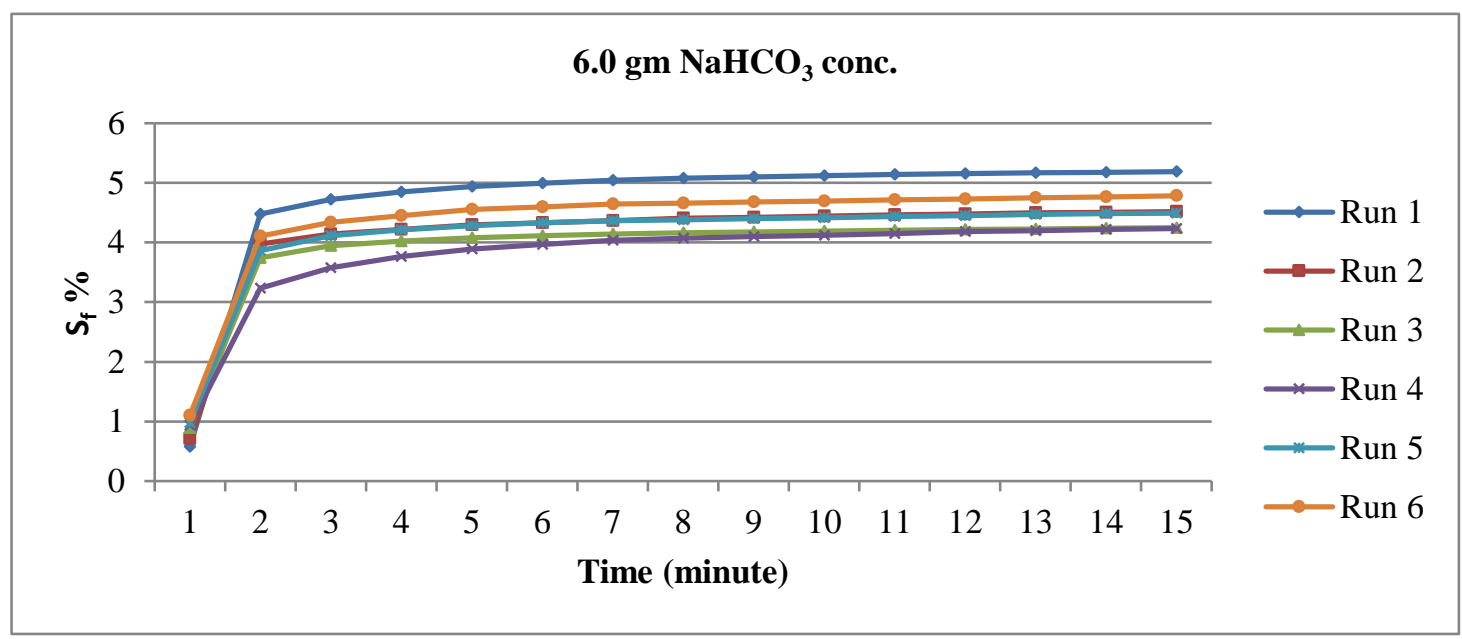

Fig.8 Third Phase: The Relation between Final Solid Content and Retention Time 


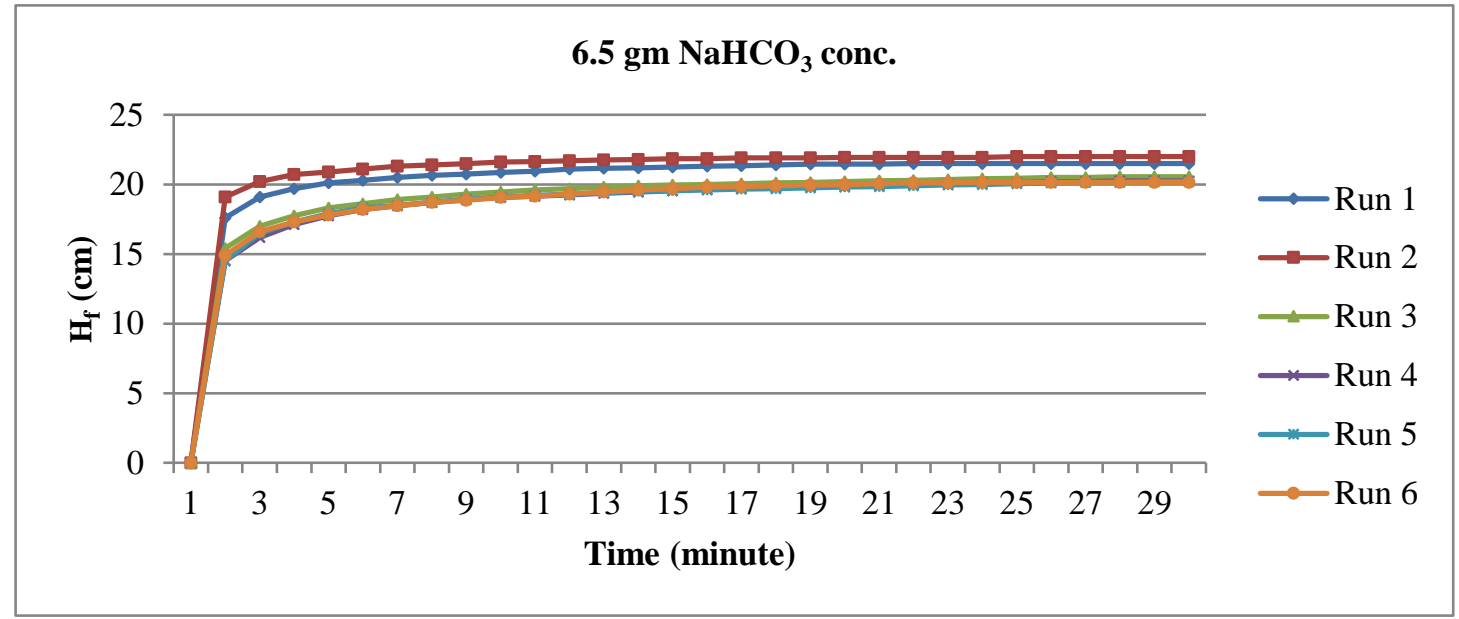

Fig.9 Fourth Phase: The Relation between Final Liquor Height and Time

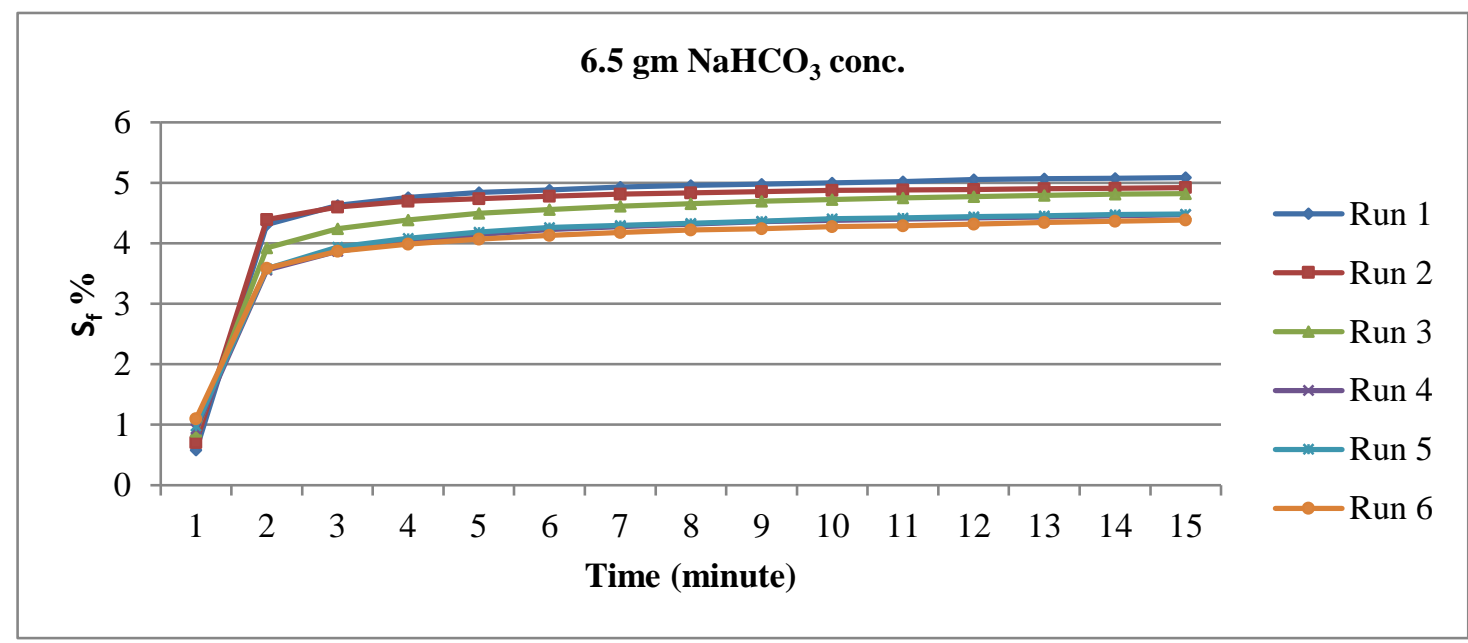

Fig.10 Fourth Phase: The Relation between Solid Content and Retention Time

From the previous phases, we find that the solid content has reached the maximum value at the Third Phase; then, it increased a little in the Fourth Phase.

Sodium bicarbonate and hydrochloric acid are harmless substances.

Furthermore, the TDS values ranged (from 1800 to 2500$) \mathrm{mg} / \mathrm{L}$; and the supernatant sludge will returned back to the head of wastewater treatment plant.

As shown in (Fig. 11), we find a dramatic difference in the results; and the superiority of the results that have been reached on the search, results in a comparison. In (Medhat et al. 2002), the experimental apparatus is composed of two parts as follows: a gas dissolution system and a bubble flotation cell. $\mathrm{CO} 2$ gas dissolved directly into waste activated sludge. The initial water content was about $0.5 \%$, and the final solid content was (2-3) $\%$.

\section{Cost Estimation}

$\mathrm{HCl}$ consumes about $3 \mathrm{~L} / \mathrm{m}^{3}$, with the cost of L.E. 40.

$\mathrm{NaHCO}_{3}$ consumes about $6 \mathrm{Kg} / \mathrm{m}^{3}$, with the cost of L.E. 20.

The cost of chemicals is about L.E. $/ \mathrm{m}^{3} 60$. 


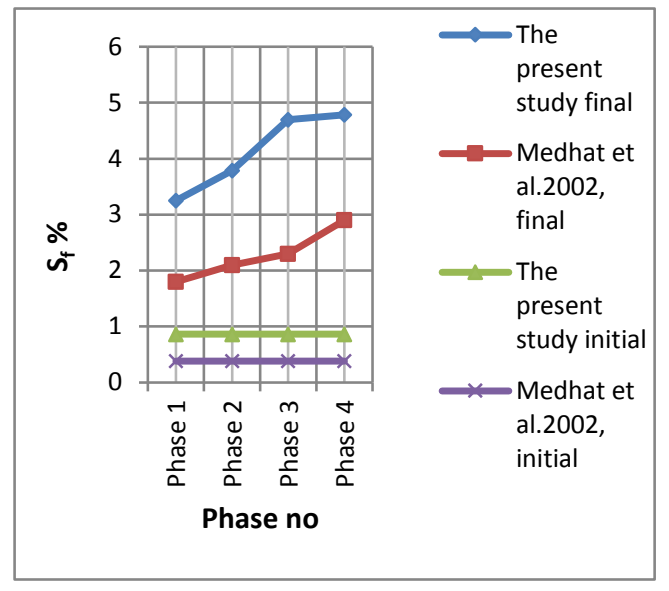

Fig.11 A Comparison between the Current Results and Medhat et al. [2] Results

\section{Conclusion}

[1] The final solid content of WAS raised from (0.6-1) to (3.25-4.75), using direct addition of $\mathrm{NaHCO}_{3}$ concentration from (5-6.5) gm/L.

[2] The $\mathrm{pH}$ value of separated liquor ranged between 5.7 and 6.58 .

[3] The current floatation cell gives better results, compared to the conventional pressurized $\mathrm{CO} 2$ cells; therefore, the effectiveness of $\mathrm{CO} 2$ gas flotation was confirmed.

\section{References}

[1] Andreoli, Cleverson Vitorio, Marcos Von Sperling, and Fernando Fernandes. (2007), "Sludge treatment and disposal. Publisher: IWA Publishing, Publication date: 1/5/2007, Series: Biological Wastewater Treatment Series, Pages: 260.

[2] Medhat El-Zahar and K. Fujisaki. (2002), "Flotation of Waste Activated Sludge by Use of Carbon Dioxide Gas", Proceedings of ENVIRO $2002 \quad$ International Conference and Exhibition, 7-12, April, Melbourne, Australia.

[3] Rubio, J., M. L. Souza, and R. W. Smith. (2002), "Overview of Flotation as a Wastewater Treatment Technique". Minerals Engineering 15.3 (2002): 139-155.
[4] Zabel, Th F. (1992), "Flotation in water treatment." Innovations in Flotation Technology. Springer Netherlands, 1992. 431-454.

[5] Schulze, H. J., et al. (1989), "Investigations of the Collision Process between Particles and Gas Bubbles in Flotation - A Theoretical Analysis". International Journal of Mineral Processing 27.3 (1989): 263 278.

[6] Medhat El-Zahar (2010), "Dewatering Waste Activated Sludge Using Greenhouse-gas Flotation Followed by Centrifugation", International Journal of Environmental Science and Development (IJESD), ISSN 20100264, Vol. 1, No. 2, pp. 199-205.

[7] Medhat El-Zahar (2009), "Dewatering Waste Activated Sludge Using Dissolved-gas Flotation Followed by Filtration", International Water Association (IWA) publishing, Journal of Water and Climate Change, ISSN: 2040-2244, Vol. 1, pp. 147-153, February 2010.

[8] Krofta, M., and L. K. Wang. (2000), "Flotation Engineering, Technical Manual No. Lenox". (2000): 1-06.

[9] Wang, Lawrence K., Edward M. Fahey, and Zucheng Wu. (2005), "Dissolved Air Flotation". Physicochemical

Treatment Processes. Humana Press, 2005. 431-500.

[10] Edzwald, J. K. (1995), Principles and Applications of Dissolved Air Flotation. Water Sci. Technol. 31 (34), 1-23.

[11] Zabel, Th F. (1985), "The advantages of dissolved-air flotation for water treatment". Journal (American Water Works Association), 42-46. 